\title{
NOTES ON UNCOMMON BIRDS AND MAMMALS NEAR CAPE CHURCHILL, MANITOBA
}

TIMOTHY J. MOSER and DONALD H. RUSCH, Wisconsin Cooperative Wildlife Research Unit, University of Wisconsin, Madison, Wisconsin. 53706

This paper records the occurrence, or possibly changing status, of uncommon birds and mammals in tundra habitat near Cape Churchill, Manitoba $\left(58^{\circ} 46^{\prime} \mathrm{N}, 93^{\circ}\right.$ $\left.16^{\prime} \mathrm{W}\right)$. Jehl and Smith, and Cooke et al. recently described the avifauna of the Churchill region. ${ }^{2}$ Sightings of 25 bird species reported by them as rare or uncommon and 4 mammals rarely found inhabiting tundra or this locale are noted. These observations were made in the "coastal tundra" zone of the Hudson Bay Lowlands from April to August 1981-84 and June-July 1985.4 The study area lies $58 \mathrm{~km}$ east southeast of Churchill, within $5 \mathrm{~km}$ of Hudson Bay, and more than 15 $\mathrm{km}$ beyond the treeline. It is characterized by poor drainage, coastal sedge meadows and relict beach ridges. Erect woody vegetation on the area is limited to willows (Salix spp.) in isolated clumps or bordering ponds, and occasional White Spruce (Picea glauca), less than $2 \mathrm{~m}$ tall, along inland beach ridges. Observations were made while conducting research on reproductive biology of Canada Geese.

\section{Birds}

Common Loon Loons were sighted occasionally in the third week of June 1981-84 and throughout July 1982.

American Bittern The only observation was on 27 May 1984.

Ring-necked Duck A raft of eight was seen on a coastal pond on 17 June 1984.

Greater Scaup One nest was found with nine eggs on 23 June 1985. Frequently seen during molt.
Bufflehead One pair was observed near the coast on 5 June 1984.

Bald Eagle One adult was observed flying north on 22 June 1984.

Rough-legged Hawk One nest (four eggs) was discovered 17 June 1981 and subsequently found destroyed. In 1984 three nests (three, two and one eggs) were found on 13, 15 and 22 June, respectively. Two nests were unsuccessful and one's fate unknown. Birds were first observed on 17 May 1981 and 19 May 1984. In 1985 , three active and two apparently unsuccessful nests were found. One nest found on 18 June contained five eggs and was on top of our 12-m high observation tower. This nest was still active on 27 June. Another nest located on a boulder contained five eggs on 12 June but was empty on 24 June. The third active nest was found on 30 June on a 20-m high metal tower.

Peregrine Falcon Peregrines were observed from early May to mid-June 1982 (one bird) and 1984 (two birds). Stoops on Willow Ptarmigan, Snow Bunting, Horned Lark, Arctic Hare and an unidentified sandpiper were witnessed.

Gyrfalcon Sightings of Gyrfalcon occurred on 5 May 1981, 9 May 1982 and 26 June 1984.

Pectoral Sandpiper In June 1983 and 1984 males were observed performing courtship displays, described as "hooting," over several sedge meadows. ${ }^{3}$ 
This behavior was not seen in this area during observation periods from 1971-1982. Although females usually nest near or within the male's territory no nests were found. ${ }^{3}$ This species has been considered a rare - uncommon spring migrant and common fall migrant. ${ }^{2}$ There is no breeding record for Pectoral Sandpipers in Manitoba; these observations suggest they bred there in 1983 and 1984 .

Upland Sandpiper One was sighted on a beach ridge $1 \mathrm{~km}$ from the coast on 26 June 1984.

Red Phalarope These phalaropes were seen uncommonly 1981-1984. Peak numbers were 20 in 1981 and 37 in 1982. One male repeatedly returned to the same tussock area when flushed by us in late June 1983 but no nest was found.
Pomarine Jaeger One was sighted in 1982. They were occasionally sighted June-July 1983 and June 1984.

Parasitic Jaeger Two nests were found in 1985 on 21 and 22 June. Each contained two eggs.

Mourning Dove A single bird was observed 5-20 July 1983.

Great Horned Owl One was recorded in willows on 4 July 1982.

Northern Flicker A flicker was observed once on 22 May 1982.

Eastern Kingbird One was sighted on 2 July 1981.

Tree Swallow One was seen on 17 June 1984.

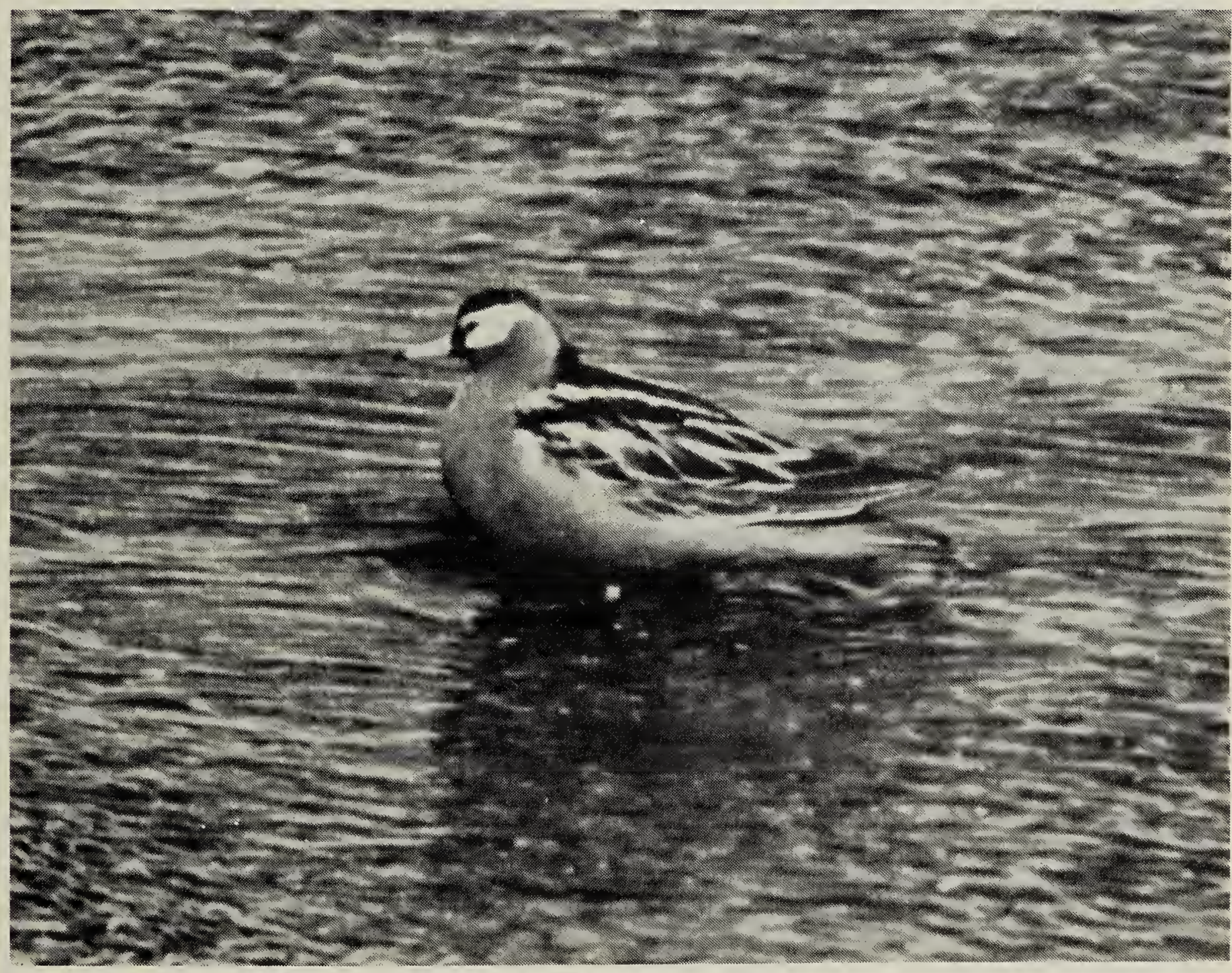

Red Phalarope

Jim Hamilton 
Barn Swallow There were three observations: a single on 12 May, two 23 July 1981 and another single 20 July 1983.

Common Raven A nest found on a 20-m high tower contained five young on 30 June 1985.

Yellow-rumped Warbler One was sighted on 31 May 1984.

Yellow-headed Blackbird A female was observed on 15 June 1984.

Dark-eyed Junco One bird was seen on 30 April 1982. A carcass, apparently killed or scavenged by an avian species, was found $1 \mathrm{~m}$ away 4 hours later.

Harris' Sparrow Observations were in late May of 1981 and 1982.

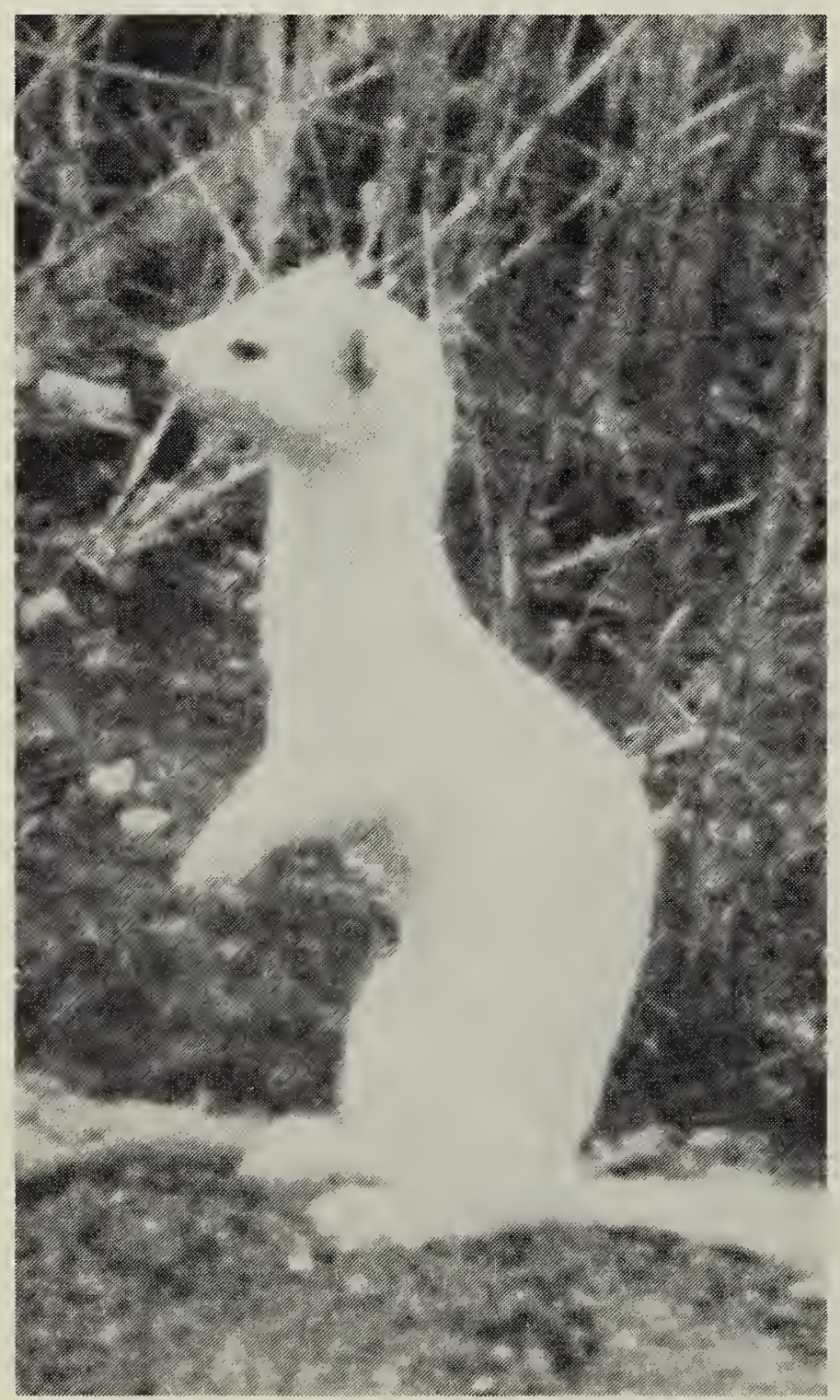

Ermine

\section{Mammals}

Ermine One individual was seen under a White Spruce on 14 June 1982.

Beaver Single Beaver were seen within $2 \mathrm{~km}$ of the coast on 27 May 1982 and 26 June 1984. A desiccated beaver carcass was found near Cape Churchill in June 1985.

Muskrat Sign in the form of runways was observed in all years. A house composed of sedges was found on 14 June 1982 and individuals were seen occasionally in May and June of 1982 and 1984.

Arctic Hare One individual in winter pelage was seen on 10 and 12 May 1984.

\section{Acknowledgements}

We thank field assistants S. DeStefano, M. Hay and D. Orthmeyer. We acknowledge the help of $M$. Gillespie (Manitoba Department of Natural Resources) and the many agency and university personnel who participated in field work on Cape Churchill. Support for the study of Canada Geese was provided by agencies of the Mississippi Flyway Council.

1 COOKE, F., R.K. ROSS, R.K. SCHMIDT and A.J. PAKULAK 1975. Birds of the tundra biome at Cape Churchill and La Perouse Bay. Can. Field-Nat. 89:413-422.

2 JEHL, J.R., Jr. and B.A. SMITH 1970. Birds of the Churchill region, Manitoba. Man. Mus. of Man and Nature, Winnipeg. Special Publ. No. 1.87 pp.

${ }^{3}$ JOHNSGARD, P.A. 1981. The plovers, sandpipers, and snipes of the world. Univ. of Nebraska Press, Lincoln. 493 pp.

4 WELLEIN, E.G. and H.G. LUMSDEN 1964. Northern forests and tundra. In Waterfowl tomorrow. Ed. J. P. LINDUSKA. U.S. Dept. of Interior, Washington. pp. 67-76. 